\title{
Multiple factor model for the assessment of external factors impact on the quality of life of able-bodied people in retirement age
}

\author{
Alena Khaperskaya*, Galina Barysheva, Olga Nedospasova, and Irina Pavlova \\ National Research Tomsk Polytechnic University, Lenina Str., 30, 634050 Tomsk, Russia
}

\begin{abstract}
This paper deals with the external factors that have an impact on the quality of life of able-bodied people in retirement age. Perspectives of the analysis of the factors and assessment of the effects of socioeconomic institutions on labor activity of economically active people in retirement age are proven. As an example, a socio-demographic factor is used as well as physical factors of the environment. The multifactor evaluation model of the impact of socio-demographic factors on the quality of life of able-bodied people in retirement age was developed based on the summary data on subjective assessments of older people's satisfaction with various aspects of their labor activity.
\end{abstract}

\section{Introduction}

For now, the expert community increasingly focuses on the ability of socio-economic systems (in our case, institutions) to contribute to improving the quality of life of older people. This is owing to global demographic aging which requires modern institutions to adapt to new challenges including the changing age structure of the economically active population and the extension of the labor activity beyond the limits of economically active age. The absolute number of older people and their share in the population, including those that continue labor activity, is growing all over the world. In this regard, the important research issue is studying the factors influencing on employment of the older generation exercised through the institutions of wage labor, entrepreneurship, and work in the household. The significant role among analyzed institutions belongs to personal psychological factors, individual aging strategies, the role of labor activity in the subjective conceptions of the quality of life, the ability of older people to face the challenges and stresses and to use their own resources to adapt to objective age-related changes [1]. However, it is important to consider the presence of the system breaks in the institutional environment and the existence of significant dysfunctions in cooperation between institutions when releasing the resource potential of the older generation, both in general and in relation to the labor activity of older people (they are related to the economic sphere, social sphere, and health care sphere) [2].

The analysis of foreign and domestic literature allows us to identify external factors influencing the quality of life of the older generation (Table 1)

${ }^{*}$ Corresponding author: khape@mail.ru 
Table 1. Factors of life quality in elderly.

\begin{tabular}{|c|l|}
\hline Factors & \multicolumn{1}{|c|}{ Characteristics } \\
\hline Socio-demographic & $\begin{array}{l}\text { age, socio-economic status, income level, insurance, job } \\
\text { reliability, job responsibilities, working schedule, working } \\
\text { conditions, distance traveled to work, education }\end{array}$ \\
\hline $\begin{array}{c}\text { The environment } \\
\text { and social resources }\end{array}$ & $\begin{array}{l}\text { Living conditions, participation in recreational activities, use of } \\
\text { preferences, assistance in housekeeping, skills }\end{array}$ \\
\hline $\begin{array}{c}\text { State of health and } \\
\text { health maintenance }\end{array}$ & $\begin{array}{l}\text { drinking alcohol, smoking, compliance with diet, physical } \\
\text { exercise, sleep quality, satisfaction with the health system }\end{array}$ \\
\hline $\begin{array}{c}\text { Psychological } \\
\text { factors }\end{array}$ & level of anxiety, social well-being, optimism, ambitions \\
\hline
\end{tabular}

According to J. Rowe and R. Kahn, other factors include engagement with life including social activity, receiving support, and having a trusted person [7].

The authors indicated the most significant factors and their subcategories characterizing the main socio-economic institutions in the field of labor activity and assessed their impact on the quality of life of the older generation. Assessment of the factors impact level on the quality of life of the older generation was calculated using a specially developed algorithm (Fig.1)

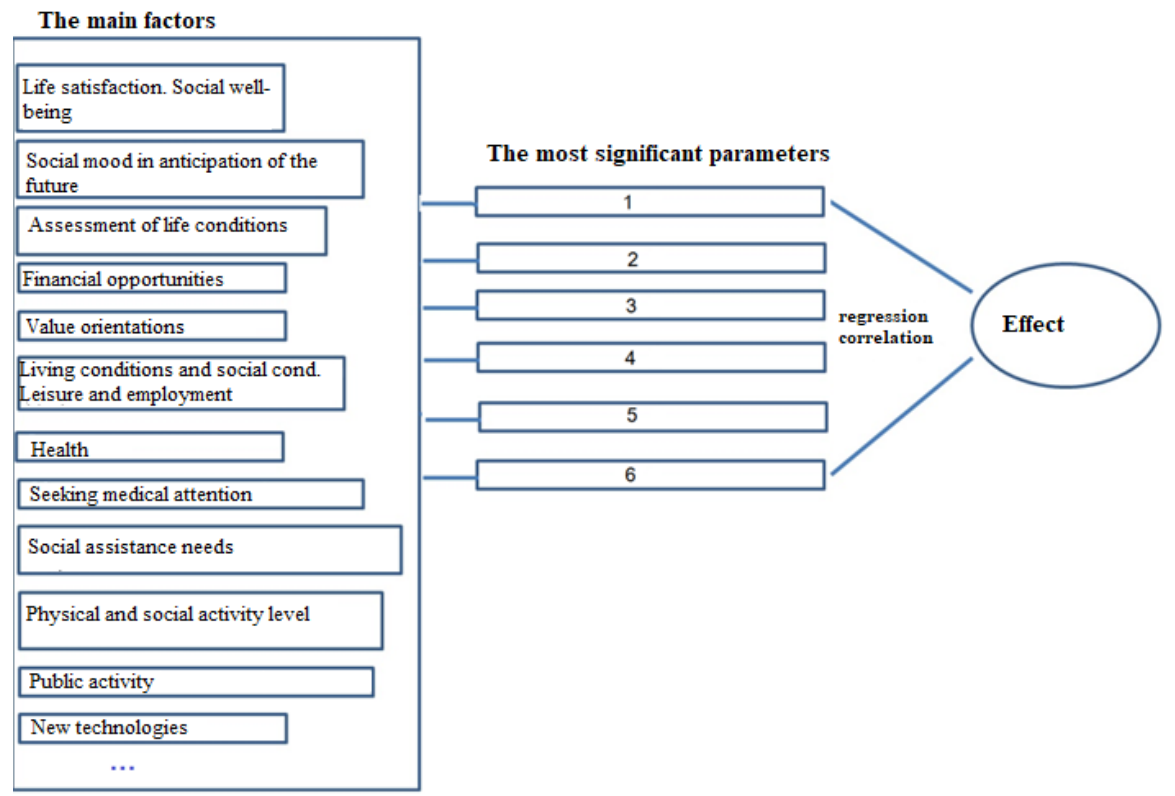

Fig. 1. The factors impact level on the quality of life of the older generation identification algorithm.

Considering that labor activity is one of the main driving forces in human life, regardless of age, the authors maintained the position that its low level (unemployment or underemployment) has a negative effect on the economic and (or) social status of the person. The analysis showed that the labor activity potential of the Russian 
citizens in older age groups is quite high, but the older workers don't fully utilize its significant part (according to their subjective opinion) [3].

\section{Methods of the forming of a multivariate model of impact assessment}

In response to the current state of the scientific problem highlighting the role of the institutions in improving the quality of older people's lives, the decision was made on the necessity of developing the multiple factor assessment model for the assessment of the impact of socio-economic institutions activity on the quality of life of the older generation. In the course of developing the model the decision was made to start by considering a bigger issue: the combination of all models of a comfortable environment for living, communication, education, and work of the older generation, then to reveal, assess, and visualize its key elements, possibilities and results of the comfortable environment creation. However, the list of external factors has been reduced due to the angle of research chosen: economically active older people's life quality research. In that connection, the factors directly related to employment were chosen (Table 2).

Table 2. Factors and results of elderly people life quality in the working process.

\begin{tabular}{|l|c|c|c|c|}
\hline & $\begin{array}{c}\text { Found it } \\
\text { difficult to } \\
\text { answer }\end{array}$ & $\begin{array}{c}\text { Very } \\
\text { satisfied }\end{array}$ & $\begin{array}{c}\text { Not very } \\
\text { satisfied }\end{array}$ & $\begin{array}{c}\text { Not } \\
\text { satisfied at } \\
\text { all }\end{array}$ \\
\hline $\begin{array}{l}\text { Level of salary } \\
\text { satisfaction }\end{array}$ & 0 & 7.6 & 7.9 & 1.9 \\
\hline $\begin{array}{l}\text { Level of job reliability } \\
\text { satisfaction }\end{array}$ & 0 & 13.5 & 3.5 & 0.4 \\
\hline $\begin{array}{l}\text { Level of job } \\
\text { responsibilities } \\
\text { satisfaction }\end{array}$ & 0 & 14.2 & 2.9 & 0.3 \\
\hline $\begin{array}{l}\text { Level of working } \\
\text { schedule satisfaction }\end{array}$ & 0 & 15.5 & 1.7 & 2.0 \\
\hline $\begin{array}{l}\text { Level of working } \\
\text { conditions satisfaction }\end{array}$ & 0 & 14.0 & 3.1 & 3.0 \\
\hline $\begin{array}{l}\text { Level of distance } \\
\text { traveled to work } \\
\text { satisfaction }\end{array}$ & 0 & 13.7 & 3.2 & 5.0 \\
\hline
\end{tabular}

The data from Table 2 represent the research team's results with the data of the comprehensive monitoring of the population living conditions in 2018, its generalization, and systematization. The positive and negative impacts of separate factors (considering the impact level) presented, according to Table 2, in the form of a spider diagram in Figure 2. 


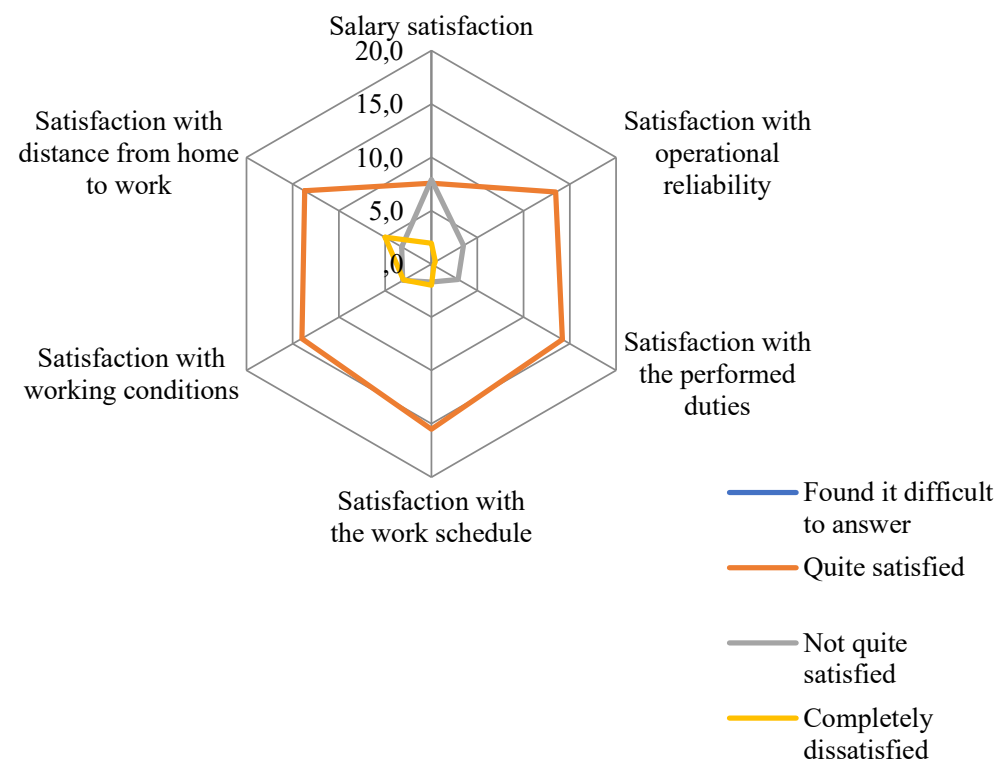

Fig. 2. Levels of positive and negative impacts of separate factors related to labor activity of older people and quality of life.

According to the algorithm (Figure 1), the task was to choose institutions that have a positive impact on older people life quality or don't have an impact at all based on the calculated percentage of the appropriate factor in their overall volume (as a combination of possible scenarios - results of labor institutions' activities) (Table 3 ).

Table 3. Positive and negative scenarios of changing the quality of older people's lives as a result of the labor institutions' activities.

\begin{tabular}{|c|c|c|c|c|c|}
\hline Positive & $\begin{array}{l}\text { Percent } \\
\text { age in } \\
\text { the } \\
\text { overall } \\
\text { volume }\end{array}$ & $\begin{array}{c}\text { Score } \\
\text { from } 0 \\
\text { to } 5 \\
\text { (P) }\end{array}$ & Negative & $\begin{array}{l}\text { Percen } \\
\text { tage in } \\
\text { the } \\
\text { overall } \\
\text { volum } \\
\text { e } \\
\end{array}$ & $\begin{array}{l}\text { Score from } \\
0 \text { to } 5(P)\end{array}$ \\
\hline $\begin{array}{l}\text { Level of job reliability } \\
\text { satisfaction }\end{array}$ & 0.81 & 4 & $\begin{array}{l}\text { Level of salary } \\
\text { satisfaction }\end{array}$ & 0.45 & 2 \\
\hline $\begin{array}{l}\text { Level of job responsibilities } \\
\text { satisfaction }\end{array}$ & 0.87 & 4 & $\begin{array}{l}\text { Participation in } \\
\text { recreational activities }\end{array}$ & 0.17 & 1 \\
\hline $\begin{array}{l}\text { Level of working schedule } \\
\text { satisfaction }\end{array}$ & 0.94 & 5 & Use of preferences & 0.19 & 1 \\
\hline \multirow{2}{*}{$\begin{array}{l}\text { Level of distance traveled to } \\
\text { work satisfaction }\end{array}$} & \multirow[t]{2}{*}{0.87} & \multirow[t]{2}{*}{4} & $\begin{array}{l}\text { Assistance in } \\
\text { housekeeping }\end{array}$ & 0.36 & 2 \\
\hline & & & Skills & 0.45 & 2 \\
\hline Optimism level & 0.74 & 4 & \multirow{4}{*}{$\begin{array}{l}\text { Level of demand for } \\
\text { services }\end{array}$} & \multirow{4}{*}{0.47} & \multirow{4}{*}{2} \\
\hline Shopping & 0.51 & 3 & & & \\
\hline $\begin{array}{l}\text { Satisfaction with living } \\
\text { conditions for last 2-3 years }\end{array}$ & 0.50 & 3 & & & \\
\hline $\begin{array}{l}\text { Satisfaction with life in } \\
\text { general }\end{array}$ & 0.84 & 4 & & & \\
\hline
\end{tabular}


The socio-economic institutions' activity impact is calculated on the basis of expert assessment of the indicator's weight (because the process of assigning weights to each indicator of institutions' spheres of influence can't be correctly mathematically formalized). The assessment was performed by the experts of the International Research Laboratory for Technologies of Senior Citizens Well-Being Improvement. A simple scoring method was used assigning the weights to the indicators in such a way that their sum was equal to 1 (data is provided in Table 4).

$$
E=\sum_{0}^{j} \mathrm{Wj} \times B \mathrm{j}
$$

Table 4. Expert judgments.

\begin{tabular}{|l|c|c|c|c|c|c|c|}
\hline \multicolumn{1}{|c|}{ Indicator } & \multicolumn{7}{|c|}{ Indicator weight (Wj) } \\
\hline $\begin{array}{c}\text { Expert } \\
\text { level of salary } \\
\text { satisfaction }\end{array}$ & 0.29 & 0.28 & 0.45 & 0.33 & 0.25 & 0.25 & 0.28 \\
\hline $\begin{array}{l}\text { level of job } \\
\text { reliability } \\
\text { satisfaction }\end{array}$ & 0.21 & 0.18 & 0.18 & 0.02 & 0.25 & 0.28 & 0.3 \\
\hline $\begin{array}{l}\text { level of job } \\
\text { responsibilities } \\
\text { satisfaction }\end{array}$ & 0.25 & 0.18 & 0.21 & 0.15 & 0.07 & 0.15 & 0.2 \\
\hline $\begin{array}{l}\text { level of working } \\
\text { schedule } \\
\text { satisfaction }\end{array}$ & 0.1 & 0.09 & 0.06 & 0.1 & 0.06 & 0.09 & 0.08 \\
\hline $\begin{array}{l}\text { level of working } \\
\text { conditions } \\
\text { satisfaction }\end{array}$ & 0.08 & 0.09 & 0.06 & 0.2 & 0.25 & 0.12 & 0.1 \\
\hline $\begin{array}{l}\text { level of distance } \\
\text { traveled to work } \\
\text { satisfaction }\end{array}$ & 0.07 & 0.18 & 0.04 & 0.2 & 0.12 & 0.11 & 0.04 \\
\hline Amount & 1 & 1 & 1 & 1 & 1 & 1 & 1 \\
\hline
\end{tabular}

Formula 1 and expert judgments were used to calculate the value of the real impact of the activity of socio-economic institutions related to the labor activity on the quality of life of the older generation (Table 5).

Table 5. Calculation of the expected and desired values of the impact of the activity of socioeconomic institutions related to the labor activity on the quality of life of the older generation.

\begin{tabular}{|l|c|c|c|c|}
\hline Indicator & $\begin{array}{l}\text { Expert } \\
\text { weight }\end{array}$ & $\begin{array}{l}\text { Real } \\
\text { score }\end{array}$ & $\begin{array}{l}\text { Real value of } \\
\text { the impact }\end{array}$ & $\begin{array}{l}\text { Expected value } \\
\text { of the impact }\end{array}$ \\
\hline $\begin{array}{l}\text { level of salary satisfaction, } \\
\text { A }\end{array}$ & 0.29 & 2 & 0.58 & 1.45 \\
\hline $\begin{array}{l}\text { level of job reliability } \\
\text { satisfaction, B }\end{array}$ & 0.21 & 4 & 0.84 & 1.05 \\
\hline $\begin{array}{l}\text { level of job responsibilities } \\
\text { satisfaction, C }\end{array}$ & 0.25 & 4 & 0.1 & 1.25 \\
\hline $\begin{array}{l}\text { level of working schedule } \\
\text { satisfaction, D }\end{array}$ & 0.1 & 5 & 0.5 & 0.5 \\
\hline $\begin{array}{l}\text { level of working conditions } \\
\text { satisfaction, E }\end{array}$ & 0.08 & 4 & 0.32 & 0.4 \\
\hline $\begin{array}{l}\text { level of distance traveled to } \\
\text { work satisfaction, F }\end{array}$ & 0.07 & 4 & 0.28 & 0.35 \\
\hline Total value of the impact & & & 2.62 & 5 \\
\hline
\end{tabular}

Factor model

$\mathrm{Y}=\mathrm{A} * \mathrm{~B} * \mathrm{C} * \mathrm{D} * \mathrm{E} * \mathrm{~F}$ 
Absolute deviation of factors:

$$
\begin{aligned}
& \Delta A=\mathrm{A} 2-\mathrm{A} 1 \\
& \Delta A=0,87 \\
& \Delta B=\mathrm{B} 2-\mathrm{B} 1 \\
& \Delta B=0,21 \\
& \Delta C=\mathrm{C} 2-\mathrm{C} 1 \\
& \Delta C=0,15 \\
& \Delta D=\mathrm{D} 2-\mathrm{D} 1 \\
& \Delta D=0 \\
& \Delta E=\mathrm{E} 2-\mathrm{E} 1 \\
& \Delta E=0,08 \\
& \Delta F=\mathrm{F} 2-\mathrm{F} 1 \\
& \Delta F=0,07
\end{aligned}
$$

Changing the life quality indicator for able-bodied people in retirement age subject to changing the selected factors:

$$
\Delta Y(\Delta A)=\mathrm{A} 2-\mathrm{A} 1, \Delta Y(\Delta B)=\mathrm{B} 2-\mathrm{B} 1, \ldots, \Delta Y(\Delta F)=\mathrm{F} 2-\mathrm{F} 1
$$

The able-bodied people in retirement age life quality factor model subject to changing the selected factors:

$$
\Delta Y=\Delta Y(\Delta A)+\Delta Y(\Delta B)+\cdots+\Delta Y(\Delta F)
$$

$\Delta Y=0.003274+0.001364+0.078439+0+0.021315+0.026644$

$\Delta Y=0.131036$

\section{Analysis of the main results of the research}

In order to prove the strong connection between the factors considered and the impact on the quality of life of the economically active people in retirement age, it was necessary to calculate a multiple correlation coefficient that has a value of:

$$
R=\sqrt{1-\frac{s^{2}}{\sum\left(y-y_{0}\right)^{2}}}=0.7612 \text { (strong and direct connection) }
$$

As a result of calculations a multiple regression, the following equation was obtained:

$$
\mathrm{Y}=0.01426+0.345 \mathrm{X}_{1} \text {. }
$$

The received calculations reflect the degree of the impact: the increase of factors by 1 unit leads to improving the quality of life of the economically active people in retirement age on average by 0.345 units of measure.

The received multiple factor model can be visualized in the form of the diagram (Fig. 3) which can serve as a baseline to measure not only the deviation from the desired value but the impact of the socio-economic institutions on the labor activity of older people. 


\section{Diagram of effects}

Real effect $\quad$ Expected effect

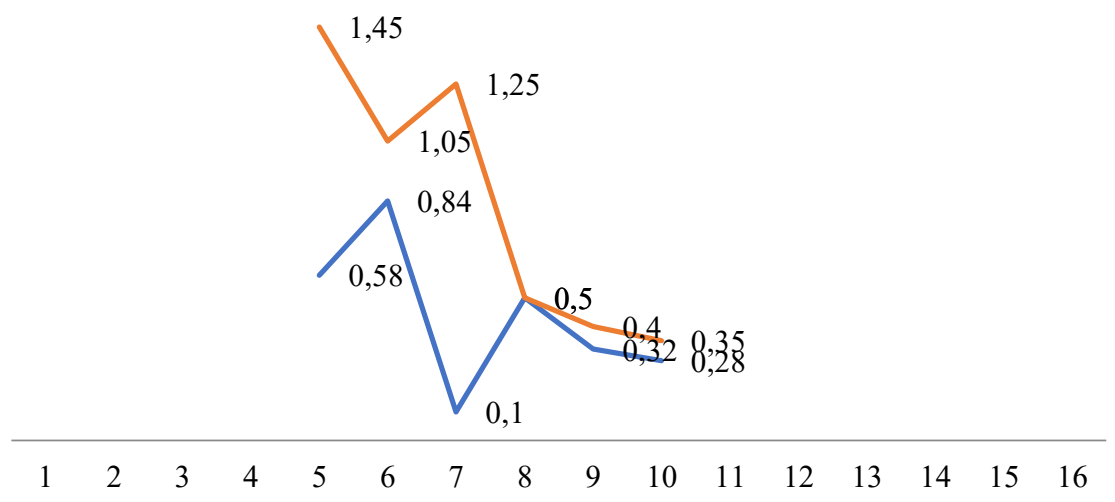

Fig. 3. Factors impact level visualization.

\section{Conclusions}

As a result of the research, the multiple factor model was obtained for the assessment of external factors (in frames of activity of socio-economic institutions) impact on the quality of life of economically active older people. This model is based on scoring the impact of the economic sphere, social sphere, and health care sphere indicators synergy, which allows taking into account the structural dynamics of the model object. The resulting model allows setting the regulatory order of indicators by growth rates, which characterizes the reference dynamics of institutions' impact on the older generation resource potential realization. The resulting model can be applicable only for Russian regions due to the nature of the data upon which it's based. The obtained results can't be replicated because of including the variable institutional factors specific to Russia in the number of endogenous factors. However, the general methodical approach is universal and applicable to assessing the impact of the activity of socio-economic institutions related to labor activity on the quality of life of the older generation.

\section{Acknowledgements}

The study is supported by the Russian Science Foundation, Project No. 19-18-00300

\section{References}

1. E. A. Sergienko, A. I. Melekhin, Human. Innovation. Management, 126, 26 (2016)

2. I. A. Pavlova, O. P. Nedospasova, G. A. Barysheva, Well-being vectors: economy and society, 39, 48 (2020)

3. I. A. Pavlova, O. P. Nedospasova, Tomsk State University Bulletin, 456, 115 (2020)

4. R. Fernández-Ballesteros, European Psychologist, 4, 3 (2006) 
5. R. Fernandez-Ballesteros, Social, Personal and Cultural Aspects. Quality of life: concept and assessment. In Advances in Psychological Science, 580 (1998)

6. R. Fernandez-Ballesteros, Applied Research in Quality of Life, 1, 21 (2011)

7. A. Kleinspehn-Ammerlahn, D. Kotter-Grühn, The Journals of Gerontology. Series B. Psychological Sciences and Social Sciences, 6, 37 (2008)

8. Federal Service state statistics, https://rosstat.gov.ru

9. J. W., Rowe, R. L. Kahn, The Gerontologist. Successful aging, 4, 433 (1997)

10. World Economic Forum. Global Competitiveness Report (2017) 